"The Fate of Territorial Engineering: Mechanisms of
Territorial Power and Post-Liberal Forms of
International Governance"
Grahame F Thompson
CSGR Working Paper No. 142/04
October 2004

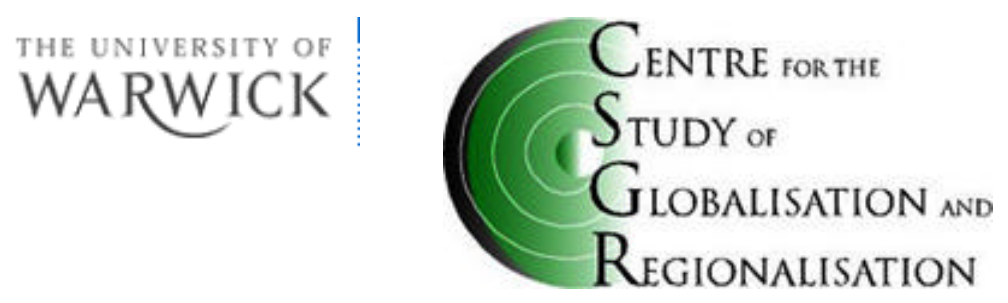




\title{
The Fate of Territorial Engineering: Mechanisms of Territorial Power and Post-Liberal Forms of International Governance.
}

Grahame F. Thompson

The Open University

CSGR Working Paper No 142/04

October 2004

\begin{abstract}
Does there exist a genuine threat to the continuation of a broadly liberal international (and domestic) order, driven by the re-emergence of religious and secular fundamentalisms? This paper assesses this issue in the context of, first the rise of territorial power and then its fate in a period of globalization and the revival of religious intolerance. The twin concepts of sovereignpower and bio-power are deployed to investigate the emergence of territorial engineering in the $18^{\text {th }}$ century. A key feature of modern fundamentalisms is that they promote and trade-off the deterritorialization of social, political, cultural and economic activity. It is argued that this is a manifestation of a new form of 'spiritual martial power'. The risks associated with these developments should not be over-exaggerated but they exists nonetheless. If this is the case, the problem becomes one of how to re-territorializes the activities and disputes engendered by this reappearance and re-emergence of spiritual martial power with its link to religious fundamentalism. Here the argument is that this requires a re-examination of the nature of international borders, and indeed a re-emphasis on their role, not just in respect to containing disorder and restoring the capacity for governance, but also as a way of re-configuring international toleration and of righting a wrong.
\end{abstract}

$\underline{\text { Key words: }}$ territory, borders, tolerance, international system, liberal governance, religious fundamentalism, sovereign power, bio-power.

Address for correspondence

Department of Politics and International Studies

The Open University

Walton Hall

Milton Keynes, MK7 6AA, UK

(g.f.thompson@open.ac.uk) 


\section{INTRODUCTION}

This paper explores the fate of 'territorial engineering' in respect to both the discourse and practice of globalization. Whilst the nature of production engineering and financial engineering are by now be quite familiar that of territorial engineering is less readily appreciated. This concept is explored in the context of first the construction of territorial power and then in regard to its possible fate in a period in which territorially base authority seems to be under some threat.

It is the twin concepts of sovereign-power and bio-power that have been central in organizing the construction of territorial power, it is argued. But beneath, or perhaps better, behind such territorially engineered power has always lurked another form of power, what is termed here a 'spiritual martial power'. Spiritual martial power has to do with the struggles formed in the context of 'blood, toil and soil', heroic virtue and legendary combat. Its connection to 'race', ethnicity and religiosity are explored, and to 'warrior politics' and to terror.

The questions posed are: 'Why and how has such a spiritual martial power reappeared in the present international context?', 'What is its relationship to sovereign-power and bio-power?', 'How has this affected the notion of territoriality in particular?', and finally, 'Can spiritual martial power be contained within the confines of a broadly liberal form of international governance?'

These questions are examined in the context of the re-emergence of different religious discourses and of religious organizations as definite practices or technologies of government. The relationship between such religious forms or organization and forms of liberal governmentality is preliminarily explored. Finally, the connection of all of this to a much wider 'ethical turn' in the conduct of governance is alluded to. 


\section{THE NOTION OF 'TERRITORIAL ENGINEERING'}

The idea of production engineering is a well established one. It involves all those material processes and technologies that go to make commodities and services that are on offer in the market place. In addition to this, there is by now a well established discourse about financial engineering. This concept is perhaps less familiar than that of production engineering but it has to do with how firms conduct a parallel activity to production engineering so as to reproduce themselves financially. It involves such activities as the raising of funds for investment, merger and takeover business, chasing subsidies of various kinds, pricing and marketing strategies, the monitoring and manipulation of company share-prices, practices of accounting for profit, etc. Often such financial engineering is associated with less than transparent or honest dealings, though there is no necessary connection to this aspect of company activity. This paper extends the idea of engineering - in the form of a deliberative activity of forging together a disparate set of mechanisms, processes and practices -- to that of a territory: hence the term 'territorial engineering'. To set the discussion going Figure 1 introduces two key considerations that are argued to have been crucial in the historical construction of the notion of a territory: those of sovereign-power and bio-power.

\section{[Figure 1 here]}

Sovereign-power was an invention of the $18^{\text {th }}$ century. It has to do with the consolidation of authority and the law into a single unambiguous pinnacle of power. Fundamentally, 'sovereign power' involves the issue of who (or what) has 'authority' over life and death. It poses in an acute way the politics of life and death (Schmitt 1985, Agamben 1995). For instance, suicide is always a crime from the point of view of sovereign-power because it challenged the right of the sovereign to have the decisive authority over death. Terrorist acts of various kinds similarly contravene sovereign-power for the same reason. They both directly challenge 'sovereignpower'.

Bio-power involves the politics of vitality, of 'man' and 'the body' - indeed of the 'body politic'. It is concerned with all those 'techniques of government' associated with the notion of a population (Foucault 1978): how to manage a population - how to nurture its health and hygiene, 
how to ensure its IQ, how to attend to its nutritional requirements, how to establish and ensure its safety and security, its welfare, its reproductive capacities, its fighting capabilities, and so on. All the moral, ethical and economic techniques classically associated with what Foucault called the 'pastor and his flock' as a mode of power (Hindess 1996). This was an invention of the $19^{\text {th }}$ century

As these two forms of power fused together we have the formation and consolidation of both a concern for and the capacity to establish a territory in the modern sense of the term, particularly the territory of the nation-state. ${ }^{1}$ It provided the space for the emergence of what I want to call 'territorial engineering'; that is, exactly how space is engineered into a territory that can be managed and run. In the modern period this is in part reproduced from definite material instruments and processes such as the issuing of passports, visas, social security numbers, driving licenses, identity cards and screening of physical features, biometric date, radar, defensive fortifications, rituals of meetings and crossings, involving various forms of classification and identification, and so on (see, for instance, Kearney 2004 and the references cited therein).

But how was territory first shaped and formed in the shadow of sovereign-power and bio-power?

One of the most interesting and ambitious books that poses this issue is Chandra Mukerji's Territorial Ambitions and the Gardens of Versailles (Mukerji 1997). It this book she argues that the garden of Versailles was emblematic of the formation of the French territorial state. As Louis XIV stepped out on to the terrace at the back of his palace at Fontainbleau he saw France laid out before him. The garden was a metaphor for the whole of France. And its construction involved the assemblage of a vast array of design skills and techniques, emergent technologies, discourses and expertise of various kinds, practical skills, instruments and equipment, artistic conceptions,

\footnotetext{
${ }^{1}$ The relationship between sovereign-power and bio-power is clearly more complex that I can go into here. For instance, there is a strong case for arguing that bio-power redefines sovereign-power; after the $18^{\text {th }}$ century biopower becomes newly constitutive of sovereign-power. Of course, for Foucault sovereign power was always something of a problematic category since it spoke exclusively to the juridico-legal aspect of power which he was at pains to criticise. In addition, bio-power itself has gone through a number of transformations; from a concern with managing a population to managing only those at risk for instance. However, despite these well taken points, I want to preserve the basic architecture of Figure 1 for analytical convenience at this stage.
} 
craft endeavors, and so on, all marshaled for the explicit purpose of creating 'France in miniature' as it were which could be surveyed and enjoyed from the vantage point of the terrace by the sovereign. It assembled and involved those very practical techniques that were themselves being used at the time to developed and consolidate the French territory as a whole; the collection of data, surveying, planning and mapping techniques, construction of earth works, the

raising of finance, the construction of fortifications, canal and bridge building, the planting of forests, the erection of symbolic architectural motifs, drainage and water management, aesthetic deliberation, establishment of transport thoroughfares, and so on, were all brought to bear in the construction and laying-out of the garden. At the centre of this was the 'tapis vert' -- the lawn that runs down the centre of the garden, an open flat space which allowed the sovereign himself to write his own particular part in this endeavour.

This is a telling and largely convincing story as to how to think about the concept of territorial engineering. But it is not the total story. And both these forms of power now seem to be under attack.

\section{SPIRITUAL MATIAL POWER AND TERRITORIAL ENGINEERING}

For instance, sovereign-power no longer seems fully able to determine the decisions over life and death - to have quite the same grip on governmental power as it used to. This is being usurped by a new religiosity and ethics of the self, where for instance, suicide becomes an instrument of religious conscience and operates as a potential technique for establishing governmental power. In addition the same is the case with terrorist assassination. These are a crime in the era of sovereignty, but now they are increasingly being employed as a way of -- if not exactly usurping that power -- then of strongly challenging it by offering an alternative claim to its legitimacy. And is bio-power such a strong element in the current configuration of governmental arrangements as the concern with - and the ability to foster and preserve -- a coherent population fades? These points thus serve to raise questions over Figure 1 as both a sufficiently general explanatory representation of the nature of 'territorial engineering' and the fate of such a 
conception in the contemporary era. What is needed first, then, is a further elaboration of the nature of territorial engineering. This is done in the context of Figure 2.

\section{[Figure 2 here]}

In respect to the twin forms of power argued to articulate the notion of territory in Figure 1, the case of Figure 2 illustrates that there has always been another type of power lurking behind these two. For want of a better term this I call 'spiritual martial power'. ${ }^{2}$ There are two aspects to this spiritual martial power: its discursive foundations and its practical organizational forms. I deal with these in turn.

In a discursive sense this conception of power is wrought from struggles formed in the context of 'blood, toil and soil', heroic virtue and legendary combat. It involves sagas and stories providing canonical images of patriotic virtue and extreme self-sacrifice, glory rooted in a morality of consequences and actual results, episodes in an endless drama of momentous stakes, whose plot is never determined in advance but always the outcome of intervention and fate. It trades on the renewal of honor and virility, the triumph of the will, and a politics of superstition.

A further feature of this martial but also spiritual ethos is that it carries a heavily romanticized vision where the nihilistic craving for violence and turmoil overcome and overwhelm any form of stable social arrangements, civil order or governance. It celebrates extreme passion in combat, continual gladiatorial contestation. It can also foster an attitude of martyrdom and aesthetic acts of terror (even an ascetics of death). But it also implies a certain form of self-mastery.

So I call the power associated with this set of attitudes and actions 'spiritual martial power' - a power that celebrates valor, endurance and suffering. This is an active power - or rather a 'power

\footnotetext{
2 This conception of a spiritual martial power is derived from a rather liberal reading of the lectures in Foucault (2003). In as much that sovereign-power is associated with the term demos and bio-power with that of ethnos, spiritual martial power would be associated with the term credos. I thank Tom Osborne for suggesting that the term 'spiritual' be added to the term martial in this formulation.
} 
of action', a power that invokes heroic effort above all else, the achievement of glory and the existence of a warrior culture.

What are some of the practical modalities of this form of power?

During the English Civil War radical elements of the New Model Army developed a critique of English history as it had unfolded since 1066. They argued that the Norman king William the Conqueror had destroyed the authentic lineage of Saxon warrior kings and their knightly valour (Foucault 2003, pp 63-84). The result was the sorry state of the monarchy in the early $17^{\text {th }}$ century against which they were fighting. They wanted to restore this corrupted tradition (corrupted by 'a foreigner' of a different 'race') and re-install the former glorious era of what is termed here spiritual martial power.

It also has its echoes in popular culture. The classic example would be Sir Walter Scott and his tales of daring do as in Ivanhoe, in the Arthurian legends, of Richard the Lionheart, and in the contemporary interest in the Lord of the Rings saga, even the Harry Potter stories. What it more, it is not unconnected to E.P. Thompson's quest for the authentic expression of the noble English working-class seen as something of a downtrodden and submerged social category, denied its proper place in history and ignored by bourgeois historiography (Valverde 2004).

Furthermore, it appears in the form of Hardt and Negri's concept of the 'multitude' that needs to rise up against the exploitative forces of globalization and Empire (Hardt \& Negri 2000). For them the multitude is a deterritorialized mass, an under-class awaiting their moment for emancipation (in some ways very much akin to Thompson's English working-class heroes).

In addition, it appears in the form of what Georgio Agamben has called 'bare-life' (Agamben 1998). Bare life is what operates in the space of the camp. A camp for him is a place where sovereignty is both suspended but seen to be operating in its most extreme form and at its limit, since it is at the moment when sovereignty is temporarily suspended that indicates what or who holds and deploys such sovereign-power; the ability to declare the camp a space of the exception. But in as much that the camp is a place where sovereign-power is suspended 'anything goes' in 
terms of decisions over life and death - Bare Life rules. Killing is neither a homicidal act (human law is suspended) nor a sacred act (religious law is suspended). The camp is a zone of indistinction' as far as life is concerned.

Finally, probably the boldest expression of such a martial power in the contemporary period would be the image or figure of a nomadic and deterritorialized warrior culture -- not just involving the de-politicized terrorist but also to some extent expressing what some traditional armed forces are argued to increasingly look like (Ignatieff 1997). Is George Bush the exemplary warrior politician? (Berman 2003)

To some this may all sound an exaggeration but it captures a certain currency of the present period. Thus, instead of the liberal and rational determinants of territorial engineering to establish classic nation-states and a state system, we would have blood, toil and soil as the determinant moments in the struggle for political control over a territory, often, though not exclusively, driven by religious conviction and organizations. And this has become transterritorial in form. It is the attachment of religious and other fundamentalism to martial power that gives them -- and martial power itself -- their current spiritual potency 3 . Whilst the 'ordinary' politics of religions (even of the fundamentalist varieties) may be philanthropic and involve charitable welfarism - in the main religious organizations work in the fields of the mass media (newspapers, TV, radio, magazines), in education, through charitable work and voluntary work -- fundamentalisms are 'orthoprax' rather than orthodox; i.e. they stress the conformity to many practices of the self and codes of conduct above strict exegesis of the scriptures, and this emphasis on confessional practices above scriptual disputation provides the space for martial power to attach itself neatly to religious fundamentalism (though such a systematic observance of ritual practices does not come at the expense of belief, of course). The mobilizatory nature of

\footnotetext{
3 The relationship between fundamentalisms (and not just religious ones) and martial power in the current period is a complex one, and one I have yet to explore in full. On the general issue of what fundamentalisms stand for see Sim (2004) and (Marty \& Appleby 1991-94). For recent analyses of religious fundamentalisms see Ali (2002) and Ruthven (2004). On the issues of religious fundamentalism and terror see Berman (2003), Juergensmeyer (2003) and Stern (2004). A number of these books are what might be termed 'popular pot-boilers' but they are instructive nonetheless and should not be dismissed out of hand.

In the following analysis not much more is said about secular fundamentalisms (like extreme neo-liberal economic analysis and policy prescriptions). But-although operating in a completely different register - there are connections between religious and secular fundamentalism in terms of martial power, particularly in the discursive drive that typifies both of them. I intend to explore this connection fully in a further paper.
} 
martial-power feeds into its warrior like status with its emphasis on action. One of its manifestations is the 'mass mobilization' and the 'mass protest' of post-ideological 'politics', though in large part fundamentalist religious terrorist groups work through secretive underground networks for obvious reasons. ${ }^{4}$

Finally in this section, although one might want to be very skeptical of the Clash of Civilizations thesis advanced by Samuel Huntingdon (Huntingdon 1996, see also Huntingdon 2004), he does pick up on some contemporary moments in the operation of martial-power. He argues that the two main monotheisms in contemporary theocratic dispute - extremist Christianity and Islam -are deterritorialized in their modalities of operation. They operate with the idea of a dynamic moving frontier of conversion impervious to national or any other borders. He also points out that the boundary between these -- where his clashes are most acute - has been a very bloody one indeed.

\section{TOLLERATION}

Give the emphasis placed upon the revival of religious extremism in accounting for the reemergence of spiritual martial power as a threat to the sovereign-power/bio-power duality that underpins territorial engineering I want now to turn to the way religious toleration was established at the end of the $17^{\text {th }}$ Century. This will open up a possible route for confronting and dealing with the rise of religious fundamentalisms in the present period, which, I should stress, is a quite different one to that of the $17^{\text {th }}$ Century. Nonetheless, there are some interesting parallels which are worth exploring.

To a large extent it was the Christian religion that 'pacified' the warrior-like spirituality of martial power in Europe during the $17^{\text {th }}$ Century. It grafted onto the extant martial power a passive form of suffering, servitude and deference. Or perhaps better expressed it remolded warrior martial power into a more precise and clinical form of martial power, one where passivity becomes heroic. This opened the way initially to the attachment of civic virtue to

\footnotetext{
${ }^{4}$ On the organizational nature of fundamentalist terrorist networks see Gunaranta (2002) and Sageman (2004).
} 
martial power, and then to the undermining, the undercutting and eventually the dilution of warrior like martial power with a new heroic attachment to civic virtue. 5

And it is the category of toleration that needs to be brought more squarely back into the international sphere, something returned to in a moment.

To a large extent toleration in its traditional sense has been seen as a supreme liberal virtue. And as a liberal virtue it is connected - closely connected - to individual conscience and private reflection. So the history of toleration is closely associated with the rise of religious toleration in particular and the rights of individuals to profess, practice and maintain whichever confessional doctrine they wish. Their adherence to this confessional doctrine is a matter of their private opinions, deliberations and consciences.

Importantly, the original political struggles to establish religious toleration within the context and boundaries of the nation state were not entirely divorced from 'international issues'. After all the Treaty of Westphalia (1648) - which began the moves towards ending the religious wars and intolerance in Europe - was an international treaty. And it was an international treaty that established probably the first ever human right - religious freedom of a sort. The Treaty allowed the confessional character of a state to be determined by its ruler with the agreement that other states should not interfere or intervene in the internal religious affairs of that state; they should respect its confessional character and refrain from inciting trouble or supporting domestic religious strife in other states (in fact this religious 'toleration' was only extended to those of Catholic, Lutheran and Calvinist faiths). A key clause in the Treaty was one allowing emigration for those who did not wish to adhere to the confessional character of the state in which they lived. In effect this clause established the right of individual religious conscience - as suggested above probably the first ever 'civil right' -- which could legitimately exist alongside the different confessional character of the state in which such individuals lived. The Treaty of Westphalia thus

\footnotetext{
5 I would suggest that Machiavelli operated as a crucial intermediate step in the transformation and move from full blown mart ial power to its civilizing pacification. For Machiavelli the morality of an action is determined by the excellence of its outcome; if it is effective it is virtuous. His morality is illusion free, where honor, self interests and fear are managed for a 'well governed polity'. Primitive necessity rules, but an enlightened self-interest is a key feature of his political outlook.
} 
established the principle of religious toleration (if not always its practice, of course). It also showed how an international treaty was of key importance in establishing the rights of individuals within their domestic territories who, potentially at least, could claim these rights against certain powers of the ruler him/herself. This Treaty also enabled the true 'nation state' to arise and consolidate, since the sovereign power was able to enforce a sole rule over a given territory, and this was legitimated by a recognition from other powers. Before that this rule had always been open to a challenge from abroad. 6

The advent of religious toleration in the Seventeenth and Eighteenth centuries involved a two step process 7 . The first was to disengage the State from the Church, asserting the formers independence from any confessional appropriation by the latter. The second step was to turn religious experience into a matter of the holding of opinions. It was in this way that radical spiritualism could be recast as a matter of private conscience. Thus -- in terms of religious belief in this case -- these two moves at one and the same time served to both 'de-politicize' the Church and create a 'public sphere' of state activity in distinction to a 'private sphere' of individual conscience or opinion. 'Domestic religious toleration' followed by being confined within the civil sphere, over which the State would adjudicate and guarantee by acting as the impartial arbitrator between any competing, but now private, interests. The defining relationship between toleration and religion is summed up by Kamen (1967): "In its broadest sense, toleration can be understood to mean the concession of liberty to those who dissent in religion" (p. 7).

Now, here is a key point in the argument. These moves - the Treaty of Westphalia and the rise of religious toleration via the separation of Church and State - represented a genuine political event. Political events are those events that declare a radical equality (Badiou 2001, Rancière

\footnotetext{
6 The Treaty of Westphalia has been afforded an exalted status in the establishment of the international system of states, one that it perhaps does not fully deserve. Whilst there is now a well established critique of this status (see for instance Teschke 2003, Rosenberg 2004) the continued existence of nation states is a reality that cannot be ignored, as will be argued at length later. The burden of the argument to come is that the 'institutions' of the nation-state and the state system need to be strengthened and de-territorialized activity re-territorialized.

7 These paragraphs draw upon Thompson 2002, and also Asad 2003, Creppell 2003, Walzer 1997 and Zagorin 2003.
} 
1999) 8 . They announce an equality where there had previously been a deep inequality. They right a wrong. By announcing the essential equality of religious beliefs and confessional practices an inequality and a wrong were attended to in a practical context of some significance. This is why the events surrounding these moves have endured for so long. They were a genuine and fundamental political event.

The question I want to raise is what would such a political event look like in the present period, also to some extent typified by a radical inequality involving religious disputation, at least ostensibly?

A further point to make about the way toleration is approached here is to try to differentiate it from an influential conception that sees toleration as an essentially repressive act (Marcuse 1965). In the case of the Marcusian approach, the extension of toleration to ones adversaries serves only to temporarily placate them in the interests of maintaining authority over the $m$ or to bolster an existing inequality in favour of the more powerful party. As against this approach, I would wish to define toleration as the cultivation of a style of behaviour that embodies a studied indifference towards difference. This is what expresses its commitment to a radical equality of treatment. In this sense, toleration is a genuinely mutual act, one that does not necessarily favour either party. Rather, whilst explicitly recognizing differences between groups, however defined, its objective is to accept these differences for what they are, share a mild interest in them, but to leave it at that and not to continually interfere. Now, this might seem to precisely license gross inequalities and deny the existence of fundamental disagreements. But it need not necessarily lead to this. As argued below, whilst it might provide a mechanism for tolerating the intolerant, it does not necessarily mean tolerating the intolerable. I try to make these distinctions clear in a moment (Ricoeur 1996)

But exactly what it is that is to be tolerated in the international sphere under present conditions? In the historical case of religious toleration it was, of course, confessional choice that was to be

\footnotetext{
8 I wish to acknowledge Claudia Aradau in drawing my explicit attention to this rather precise definition of a political event (see her essay '(In)Different politics: trafficking in women and resistance as event', Open Un iversity, 2004). I take this 'ethical' moment in the foundation of politics to be a consequence of politics being about conviction and therefore always involving an ethos.
} 
tolerated. In the contemporary period, it is suggested, toleration has mainly to do with some very difficult issues associated with the existence of disputed international borders that define distinct territorial jurisdictions. This is the main difference between toleration in the $17^{\text {th }}$ Century and toleration in the $21^{\text {st }}$ - the axis of toleration is different -- religion then, national boundaries now. Whatever the current religious based disputes exist, they are over-determined by boundary disputes, it is suggested.

And this will involve a very different type of political event to address it. I would controversially suggest that this political event involves the declaration of a fundamental equality in respect to all existent and extant international borders in the first instance. This is controversial since its might seem to involve a clear 'inequality' as existing international boundaries are often arbitrary and were imposed by occupying powers and colonial administrations. They are fiercely fought over as a consequence, or at least the subject of a constant disputation. Be that as it may, the point is that there are two sides to every border dispute, and both these positions have to be respected if toleration is to take hold. This is the nature of the radical equality to be announced here - it is to accept the necessity of a mutual recognition of the current status quo before anything more can be done. How this might be operationalized I return to in a moment. And this position is bolstered by a further recognition that peace and peaceful co-existence are very conservative objectives. Peace cannot be associated with radical change or a serious breach of the status quo - the redrawing of political and jurisdictional boundaries for instance. People have to feel safe and that their positions are not to be compromised if they are to agree to peace (rather than having peace 'imposed' upon them).

These considerations would provide the necessary pre-requisites for the re-territorialization of the emergent spiritual martial power, preventing it getting out of control and to completely overwhelm a broadly liberal international order - which it is threatening to do 9 . Thus the claim here is that only if the 'inequities' associated with borders are attended to in the manner suggested here, and developed at greater length later, will $\mathfrak{t}$ become possible to undermine

\footnotetext{
${ }^{9}$ Paul Hirst posed this nicely in one of his last published contributions before his death (Hirst 2003). He asked what were the limits to the accommodation of non-democratic, fundamentalist and religious governmental organization to the continuation of a liberal international order (p.55-58). The comments in the rest of this paper provide an initial response to this issue.
} 
religious intolerance. The issues confronted in the following analysis is how to foster the conditions for a re-territorialization of social and political activity (and by extension of economic activity as well). There are some real advantages, then, to a Westphalian system of states. It is easier to secure governance and order under such circumstances than to celebrate the emergent transnationality of political and social forces that are thought to herald the advent of a new cosmopolitan era. Under contemporary circumstances this latter is more likely to degenerate into an anarchy of warrior politics driven by the spiritual martial power associated with religious ideological disputes.

\section{BOUNDARIES}

But how are boundaries thought and constituted? 10 Boundaries exist as linked sites of difference and local oppositions. Differences and local oppositions are 'connected up'; yoked together to form entities. Thus, boundaries exist 'before' entities. Entities -- the thing-ness of social space are thus constituted by boundaries, not the reverse; thing-ness is an enduring entity, it is the quality of entitiness. In principle, then boundaries could exist without entities - they are simply sites of difference, neighborhoods of oppositions. Members and strangers only exist in relationship to boundaries, as several dimensions of difference are linked up, connected to form a boundary. Members are placed 'inside' the entity-to-be, indeed members are made up by the establishment of that boundary. There cannot be the category of a 'citizen' without the idea of a national boundary. There cannot be an illegal immigrant without this either. There cannot properly be a 'dehumanized' camp occupant without there being a camp of a certain type first.

Plans and scripts are one of the ways this yoking is done, it is in the action of scripting and narrating that pulls together a set of boundaries into a social entity with the quality of thingness (hence the importance of religious ideology in re-constituting new boundaries that ostensibly cut across existing national ones). Zones of difference are proto-boundaries than are yoked together to produce enduring entities. Of course, new differences are always being set up or emerging within groups, so how do a) old entities endure and b) new ones emerge? Old ones endure in as

10 The discussion relies heavily on Abbott 2001 and Walzer 1981. 
much that cleavages are overlapped and compacted into a cohesiveness, an assemblage of various sides and sites of difference. Thus the boundary around a corporation links up various transactions and markets to create an entity - the firm (Holmström \& Roberts 1998). The border around a territory is created by linking up various localities of difference, various frontiers of opposition. Neither space nor time can exist without boundaries from the point of view of this topological logic (Walzer 1981). As soon as an old boundary is broken a new one is formed. In the case of territories, new jurisdictions are formed. In fact the history of the $20^{\text {th }}$ Century is one of a growing number of territorial boundaries around nation states, which is illustrated in Figure 3.

\section{[Figure 3 here]}

As shown in Figure 3 there has been a quickening of the pace of national boundary formation since the ending of the second World War. So there are many more boundaries over which there could be disputes as we enter the $21^{\text {st }}$ Century. Note also that this increase in the number of countries has been accompanies by an increase in economic openness (as measured by the trade to GDP ratio). Alesina and Spolaore (2003) argue that 'globalization' (in the form of increased international trade interdependency and investment integration) has encouraged the formation of 'smaller' states (in terms of population or GDP not necessarily in terms of spatial area). ${ }^{11}$ But it is only as long as populations and territories feel economically and politically secure that this trend will continue, they suggest (see also Rieger \& Leibfried 2003).

\section{INTERNATIONAL TOLERATION}

So how might all this help to think creatively about a relatively robust complex of mutually reinforcing dimensions guiding the establishment of a tolerant and peaceful coexistence in an increasingly fragmented and antagonistically poised international system? This section experiments somewhat speculatively with a list of conditions and principles that might begin to

\footnotetext{
11 They do not suggest that there is a strong 'causal' mechanisms operating here - from globalization to smaller states -- only that the former has allowed the latter to develop, and there tends towards a reciprocal relationship between the two trends (Alesina \& Spolaore 2003, pp.192-99).
} 
offer a vocabulary for thinking about this. The concrete circumstances under which these might operate as principles or how they might be deployed is not discussed here. We start with the most obvious of these conditions, the availability of financial resources and their deployment.

\section{Finance and Money.}

A regime of international toleration requires a lot of money to be devoted to it. The current state of disorder in the international system is not unrelated to the gross inequalities that continue to exist within countries (indeed here they are growing in the advanced industrial economies) or between the rich and the poor economies (though here they are some signs that international inequality may declining slightly -- see Thompson 2004). But, without a radical redistribution of income the prospects for long-term peaceful coexistence look bleak.

However, there are issues closer to hand that could be addressed. In particularly there would need to be much more emphasis put on peacekeeping activities of various kinds and intelligence gathering. Military action is very expensive but so is peacekeeping. Peacekeeping is a growth industry, and the military know this. Some 'armed forces' have a comparative advantage in peace keeping over war-making. In many ways this is true of the British armed forces, and a lot of military personal recognize this 12 . The UK armed forces, for instance, could not prevail in any conflict overseas without the assistance of the US forces, as was demonstrated in Argentina and Iraq, and the more astute commanders and managers realize this.

If 'training for peace' were to be taken seriously by armed forces, there would be much less emphasis on hardware and more on software. However, the strategic decisions taken by the UK New Labour government have moved against this. They have gone for the hardware option (two new aircraft carriers, support for the Euro-fighter) and a watered down version of the RMA. In a

\footnotetext{
12 These comments are based upon my observations and conversations with military personnel whilst teaching at the UK Joint Services Defence College for several years. Some of the most ardent 'peaceniks' that I have met are from the army. They know that to orient themselves towards 'peace-keeping' is necessary if they are to, first of all, continue to attract funds and secondly not to loose out to 'private' peace keeping initiatives/intelligence gathering organizations that also see this as an opportunity and a growing market. If the anti-war movement were more intelligent they would try to capitalize on this dilemma for the armed forces, and try to strike up an 'alliance for peace(keeping)' with the armed forces (and against the privatization of peace)!
} 
situation where you need 'personnel-on-the-ground' for peacekeeping activities, with skills more like those of an Oxfam field-officer or an armed constabulary, these high-tech equipment options are the wrong ones.

\section{$\underline{\text { Truths and truces }}$}

Secondly, one further way to revive the lost virtue of toleration in international affairs is to emphasize the principle of 'truce seeking' above that of 'truth seeking'. Our social order is one in which truth seeking is the deeply embedded and widely deployed one. It appears in the form of the discourse "I am right and you are wrong" which animates so many aspects of our daily lives and intellectual culture. Finding who is to blame as things go wrong, and attributing guilt to those responsible are the supreme objectives of both our legal system and that of common justice. The finding of a true cause for things also lies behind the commitment to an interventionary political and economic culture.

But truces are interesting situations, perhaps more interesting than truth situations, if we have in mind the fostering of toleration. Truces are positions -- often only temporary -- in which no party is fully satisfied or which has secured all its objectives. They are neither situations of continued conflict nor of outright victory or resolution, so they avoid celebratory gloating or humiliating defeat. They are 'in between' and thus uncomfortable. Nevertheless, they are truces; what more can we ask for in world where outbreaks of conflict of some kind seem inevitable? They offer periods for reflection and trust building. They provide an occasion to seek compromise and consensus, an opportunity to build cooperation and reconciliation, an opportunity to turn 'détente' in an 'entente'. In this way truce seeking behaviors and mechanisms represent an important way of defusing potential and actual antagonistic conflicts. They are a prime example of establishing a more tolerant framework for social order.

\section{Sieges as stalemates}

If the conditions for truces cannot be found it might be possible to develop the mentality of sieges, or perhaps better expressed as 'stalemates'. Like truces, sieges/stalemates are interesting 
states of affairs. We are accustomed to think of the 'decisive battle' as the key moment in any war, and particularly in bringing about the conditions for the enemy's defeat. But historically most wars were ended 'peacefully' in the context of a siege/stalemate. In fact until relatively recently, most wars were pretty leisurely affairs. There were few actual battles, which were quickly over anyway. Most wars took the form of long marches - endless wandering about the countryside looking for the enemy - and long sieges of towns and fortifications. The (redevelopment of a 'siege/stalemate mentality' amongst modern day antagonistically poised combatants provides another opportunity for the 'temporary' interruption of conflicts. If such sieges/stalemates could be turned into semi-permanent states of affairs, in effect the equivalent of 'toleration' would have been established.

\section{Appeasement}

Perhaps more controversially, there remains something to be said for resurrecting the heavily discredited concept of 'appeasement' as a principle for the strengthening of toleration. Appeasement is a tougher category than a truce or a siege/stalemate because it requires the stronger party to genuinely give up an advantage that it could exercise if it wished. It thus requires the stronger party to be magnanimous; to forego or suppress its own interest in the name of the common good of both interests. It can also be considered as a way of tolerating the intolerant (always a problem for more conventional conceptions of toleration). This category is a 'dangerous' one, because it requires suppression of an advantage which could backfire. But the taking of such risks is a necessary feature of any system that has as its ultimate objective the strengthening of the peace overall.

\section{Separation}

Finally, however, we may have to face afresh the fact that agreement on an 'integrated' toleration is not possible to achieve. The conventional liberal wisdom is that integration and multiculturalism are the ultimate virtues for a tolerant society. 
An important salient feature of liberalism is its presumption that there exist a political community that is homogeneous enough to be governed, regulated or managed. In this case sovereignty is able to exercise its effective control because a generalized consent is in principle possible. But without this presumption the juridico-legal notion of sovereignty is unhinged. A number of centres of political capacity can exist amongst which there is no necessary presumption of social passivity and consensual agreement. Any such agreement must be negotiated or struggled for, and will only ever be contingently established.

So under these circumstances, it may be necessary to reinstate physical separated nesses as a realistic criterion for toleration. This would echo points that could be made about such international orders as the Holy Roman Empire or the Ottoman Empire, where physical separation between confessional, cultural, legal and ethnic groupings was common, even as they existed in close proximity to one another. De facto separation has tended to arise in cases of extreme antagonistic pluralism anyway, so now may be the time to embrace this more formally, and organize for it, rather than maintain the pretence of integration and multiculturalism. Properly organized and supervised, such an approach might actually enhance toleration rather than undermine it, as is often argued. It is not necessarily a 'failure' of toleration to recognize the desire of particular communities to live apart if they cannot live together. This involves a (reluctant) substitution of 'mutual extraterritoriality' with 'separate territoriality'.

After this brief discussion of separatedness of combatants it is useful to raise once again the issue of what all this toleration is about? In response, and to reiterate: the problem is that the legacy of nation state building and imperialism has left some uncomfortable, or grossly unfair, and often unsustainable 'territorial boundary problems', the inequities of which are understandably the objects of struggle for those disadvantaged by the arbitrariness of those processes. The "hand of fate' involved in nation building and imperialism has left many with an outcome that does not at all suit their purpose or expectation. Existing nation states are nothing more than 'communities of fate'. Why should those disadvantaged groups not challenge the existing boundaries of the international system and upset any carefully crafted toleration built around them? 
The response to this is of course they will. The regime of toleration suggested here does not justify the intolerable. There will always be conflict. The conception of politics deployed in this analysis perceives it as constituted by, and constitutive of, 'disagreements' and 'antagonisms'. These cannot be escaped I would suggest. They cannot be neatly 'negotiated' out of the system as a generalized 'tolerant' consensus and agreement emerges. But what the suggested regime of toleration requires as a minimum is that all sides accept to a certain extent the existing boundaries of the system as a legitimate aspect of its existence. This does require a certain compromise, a certain appreciation that the legacy it embodies carries its own egitimacy, that these boundaries cannot be destroyed at will since they have constituted their own 'new' sets of expectations and commitments, whether this is liked or not.

As suggested above, perhaps unfortunately peace is a very conservative objective. It requires parties to feel that they would be less threatened than with the existing status quo. It is risky since it might put any party at a disadvantage, making it reliant on the goodwill of others and at their convenience. This is why peace cannot be associated with radical change. It cannot be part of a major re-organization of the social order. It requires a 'de-escalation' of conflict and turmoil rather than any potential 're-escalation' of it.

In addition, it must be remembered that international peace can only be made by states. Peace movements are all very well and have their place, but they do not make peace and have not been able to put serious pressure on governments if they are intent on conflict. Witness the recent war on Iraq. Although anti-war peace movements were highly active in the USA, the UK and elsewhere, and the majority of the populations in these countries did not initially support the war, this made little difference. The problem is, states are not 'moral agents'. They are political and strategic agents who calculate the possible advantages and disadvantages of policies according to their perceived interests, survival instincts, 'hard' choices, and so on. This makes peace above all a political calculation, where moral considerations will always be secondary. 


\section{BY WAY OF CONCLUSION}

Consider Figure 4. 13 This figure sums up many of the arguments of this paper.

\section{[Figure 4 here]}

In the top half, two scenarios for the international system are sketched: antagonistic pluralism 14 and tolerant pluralism.

The suggestion in this paper is that the issue is broadly one of moving from situation 1 to 2 in the top half of the figure, not by replacing 1 by 2 but by 'surrounding' 1 by 2 so that 1 is 'squeezed' and finally 'dissolves' into 2 (thereby 'changing the regime'). ${ }^{15}$ The direction of movement thus goes from 2 to 1.

But perhaps there are other considerations and positions indicated by situations 3 and 4 shown in the bottom half of Figure 4. If we are actually in the position of situation 3 - one that might be termed 'unilateral antagonism' -- and this may be nearer the present case given the role of the USA -- then it is going to be doubly difficult to move to situation 2. But is a move from 3 to 2 likely to be more difficult that a move from 1 to 2 (by which 2 'enfolds' 1)? At this stage I leave a response to this question open.

What has been argued in this paper is that there exists a genuine threat to the continuation of a broadly liberal international (and domestic) order, driven by the re-emergence of what I have called spiritual martial power, aligned to the rise of religious and secular fundamentalisms. This risk should not be over-exaggerated but it exists nonetheless. A key feature of such

\footnotetext{
13 I thank Andy Dobson for suggesting this diagrammatic representation.

14 To be precise about this, antagonistic-pluralism is a system in which the pluralization of interests and social forces intensifies to such an extent that it becomes increasingly difficult to organize compromises and agreement between these interests and forces, and in which the usual channels of democratic activity begin to look increasingly suspect and loose their legitimacy. This new period is one often accompanied by an increase in the extent of ungovernable manic capitalism. Manic capitalism is a frenetic economic system embodying an intense and uncontrollable dynamic of competitive activity driven as much by corruption, marketeering, speculation, profiteering and mismanagement as by genuine ordered economic exchange.

15 'Changing the regime' is not the same as a 'regime change'. Regime change involves an intervention from 'outside' to change the political leadership, government or administration. Changing the regime implies a process of the application of pressure or negotiation to reform, adapt of change the structure, peacefully and with consent.
} 
fundamentalisms is that they both promote and trade-off the deterritorialization of social, political, cultural and economic activity that is seen as a feature of contemporary globalization. In the case of 'warrior politics' in particular such a deterritorialization represents a real danger. If this is the case, the issue becomes how to re-territorializes the activities and disputes engendered by this reappearance and re-emergence. Here the argument was that this requires a reexamination of the nature of international borders, and indeed the re-emphasis on their role, not just in respect to containing disorder and restoring the capacity for governance, but also as a way of re-configuring international toleration and righting a wrong. 


\section{References}

Abbott, A. (2001) 'Things of Boundaries' in Time Matters: On Theory and Method, Chicago, University of Chicago Press.

Agamben, G. (1998) Homo Sacer: Sovereign Power and Bare Life, Stanford, Cal.: Stanford University Press.

Alesina, A. \& Spolaore, E. (2003) The Size of Nations, Cambridge, Mass.: The MIT Press.

Alesina, A., Spolaore, E. \& Wacziarg, R. (2003) 'Trade, Growth and the Size of Countries', HIER Discussion Paper Number 1995, January.

Ali, T. (2002) The Clash of Fundamentalisms: Crusades, Jihads and Modernity, London: Verso.

Asad, T. (2003) Foundations of the Secular: Christianity, Islam, Modernity, Stanford, Cal.:

Stanford University Press.

Badiou, A. (2001) Ethics: An Essay on the Understanding of Evil, London. Verso.

Berman, P. (2003) Terror and Liberalism, New York: W.W.Norton \& Company.

Creppell, I. (2003) Toleration and Identity: Foundations in Early Modern Thought, London:

Routledge.

Foucault, M. (1978) The History of Sexuality Volume 1: An Introduction, London, Allen Lane.

Foucault, M. (2003) “Society Must Be Defended” (Lectures at the College de France 1975-76), New York, Picador.

Gunaranta, R. (2002) Inside Al Qaeda: Global Network of Terror, London: Hurst and Co.

Hardt, M. \& Negri, A. (2000) Empire, Cambridge Mass: Harvard University Press.

Hindess, B. (1996) Discourses of Power: From Hobbes to Foucault, Basil Blackwell: Oxford.

Hirst, P. (2003) 'The future of political studies' European Political Science, Vol.3, No.1, Autumn, pp.47-59.

Holmström, B. \& Roberts, J. (1998) 'The Boundaries of the Firm Revisited' Journal of Economic Perspectives, Vol.12, No. 4, Fall, pp.73-94.

Huntingdon, S. P. (1996) The Clash of Civilizations and the Remaking of World Order, New York: Simon Schuster.

Huntingdon, S.P. (2004) 'The Hispanic Challenge' Foreign Policy, March/April, pp.31-45.

Ignatieff, M. (1997) The Warrior's Honor: Ethnic War and the Modern Conscience, New York: Metropolitan Books.

Juergensmeyer, M. (2003) Terror in the Mind of God: The Global Rise of Religious Violence, Berkeley: University of California Press.

Kamen, H. (1967) The Rise of Toleration, New York: World University Library.

Kearney, M. (2004) 'The Classifying and Value-filtering Missions of Borders' Anthropological Theory, Vol.4 (2): 131-156.

Marcuse, H. (1965) 'Repressive tolerance' in Wolff, R.P., Barrington Moore, J. and Marcues, H. (eds) A Critique of Pure Tolerance, Boston, Beacon Books.

Marty, M.E. \& Appleby, R.S. (1991-94) Fundamentalisms Observed, Vols. 1 -4. Chicago: Chicago University Press.

Mukerji, C. (1997) Territorial Ambitions and the Gardens of Versailles, Cambridge; Cambridge University Press.

Rancière, J. (1999) Dis-Agreement: Politics and Philosophy, Minneapolis: University of Minnesota Press.

Ricoeur, P. (ed)(1996) Tolerance between Intolerance and the Intolerable, Providence, RI.: Berghahn Books.

Rieger, E. \& Leibfried, S. (2003) Limits to Globalization, Cambridge: Polity Press. 
Rosenberg, J. (2004) ‘Globalization Theory: a Post Mortem’ (j.p.rosenberg@sussex.ac.uk)

Ruthven, M. (2004) Fundamentalism: The Search for Meaning, Oxford: Oxford University Press.

Sageman, M. (2004) Understanding Terror Networks, Philadelphia: University of Pennsylvania Press.

Schmitt, C. (1985) Political Theology: Four Chapters on the Concept of Sovereignty, (trans. George Schwab) Cambridge, Mass: MIT Press.

Sim, S. (2004) Fundamentalist World: The New Dark Age of Dogma, Cambridge: Icon Books.

Stern, J. (2003) Terror in the Name of God: Why Religious Militants Kill, New York: Harper Collins.

Teschke, B. (2003) The Myth of 1648: Class, Geopolitics and the Making of Modern International Relations, London: Verso.

Thompson, G F. (2002) 'Toleration and the Art of Governance: How is it possible to "live together" in a fragmenting international system?' in Hillier, J. and Rooksby, E. (eds) Habitus: A Sense of Place, pp.67-91, Ashgate, Hampshire.

Thompson, G.F. (2004) 'Wealth and technology in historical perspective' in Brown, W. Bromley, S. \& Athreye, S. (eds) Ordering the International: History, Change and Transformation, London: Pluto Press.

Valverde, M. (2004) 'Review essay: Michel Foucault, society must be defended: Lectures at the College de France 1976-77' (m.valverde@utoronto.ca).

Walzer, M. (1981) 'The Distribution of Membership' in Brown, P.G. \& Shue, H. (eds) Boundaries: National Autonomy and Its Limits, Totowa, NJ.: Rowman and Littlefield.

Walzer, M. (1997) On Toleration, New Haven: Yale University Press.

Zagorin, P. (2003) How the Idea of Religious Toleration Came to the West, Princeton, NJ.: Princeton University Press.

Zubaida, S. (2003) Law and Power in the Islamic World, London: I.B.Tauris. 
Figure 1: Constructing Territory I

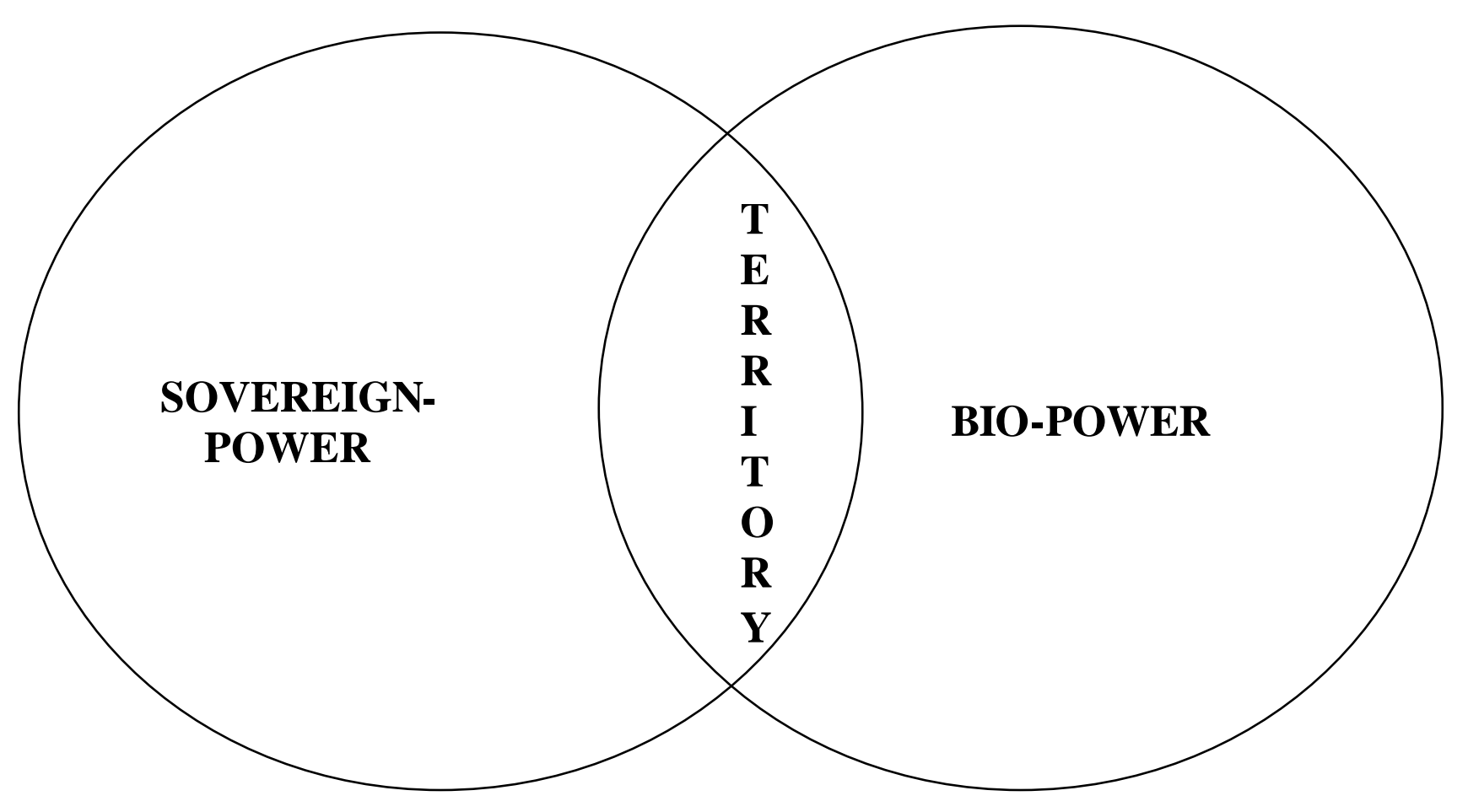


Figure 2: Constructing Territory II

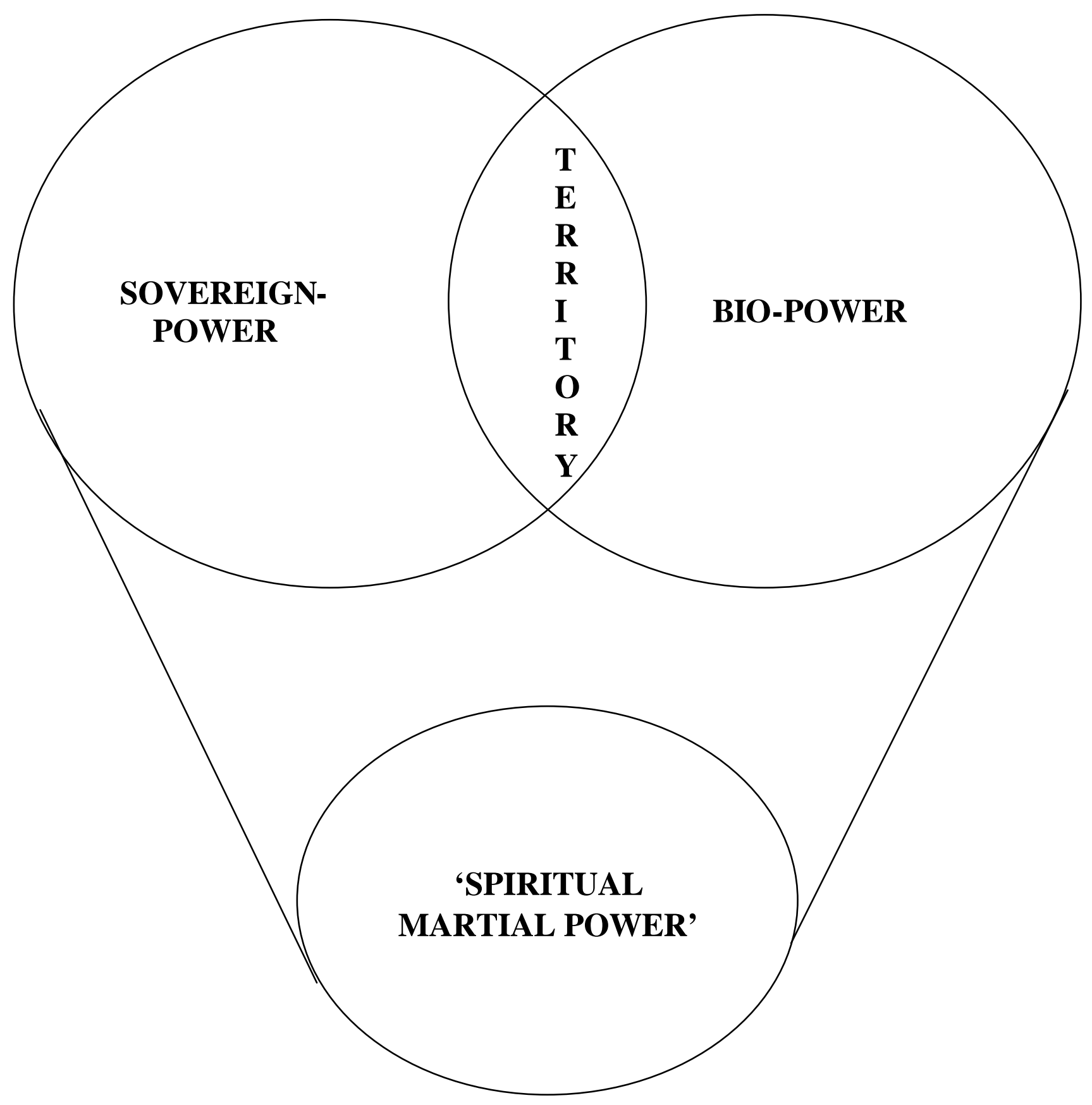


Figure 2. Trade Openness and the Number of Countries

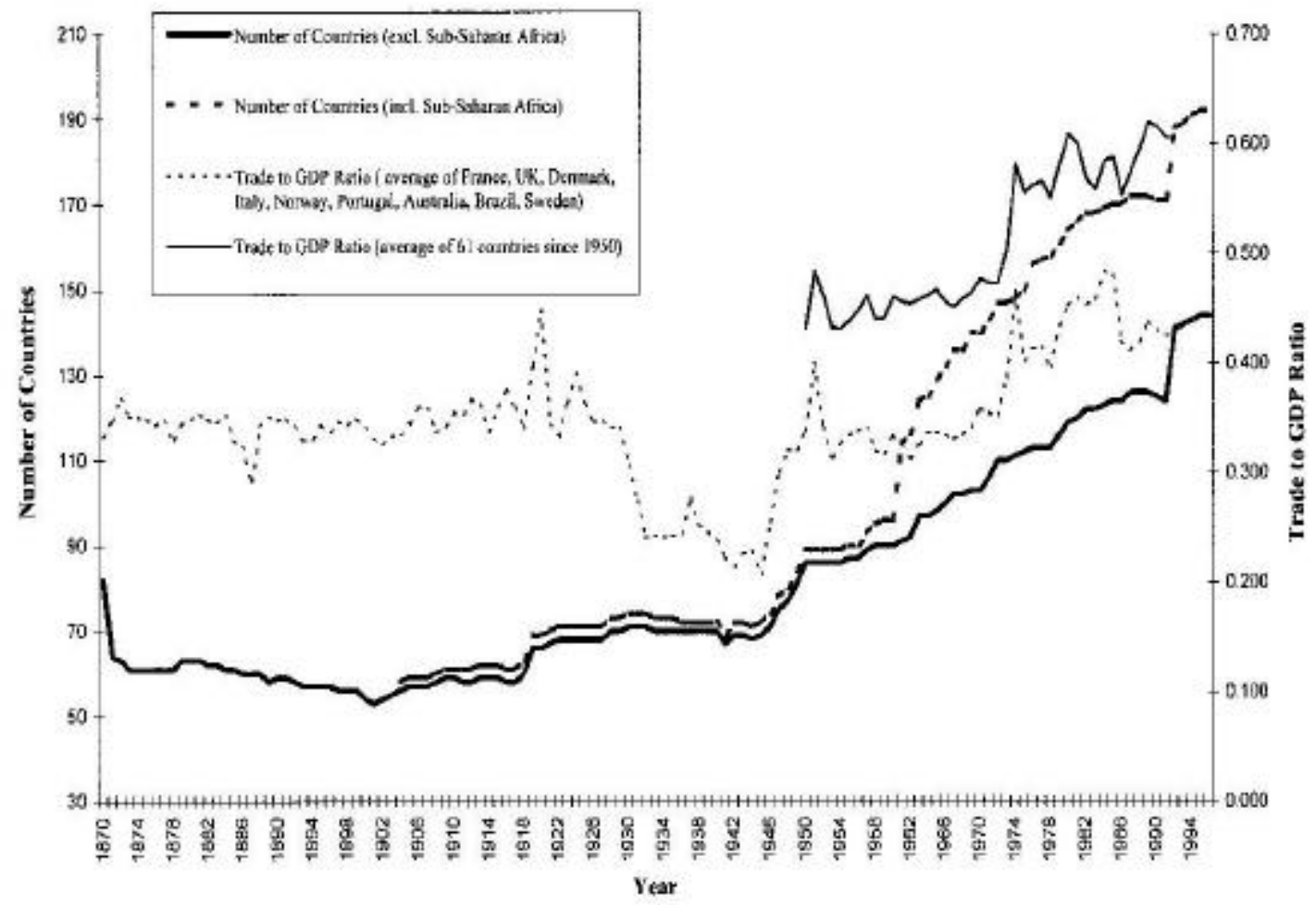

Figure 3: Number of Countries and Trade Openness.

Source: Alesina et al, 2003, Figure 2. 

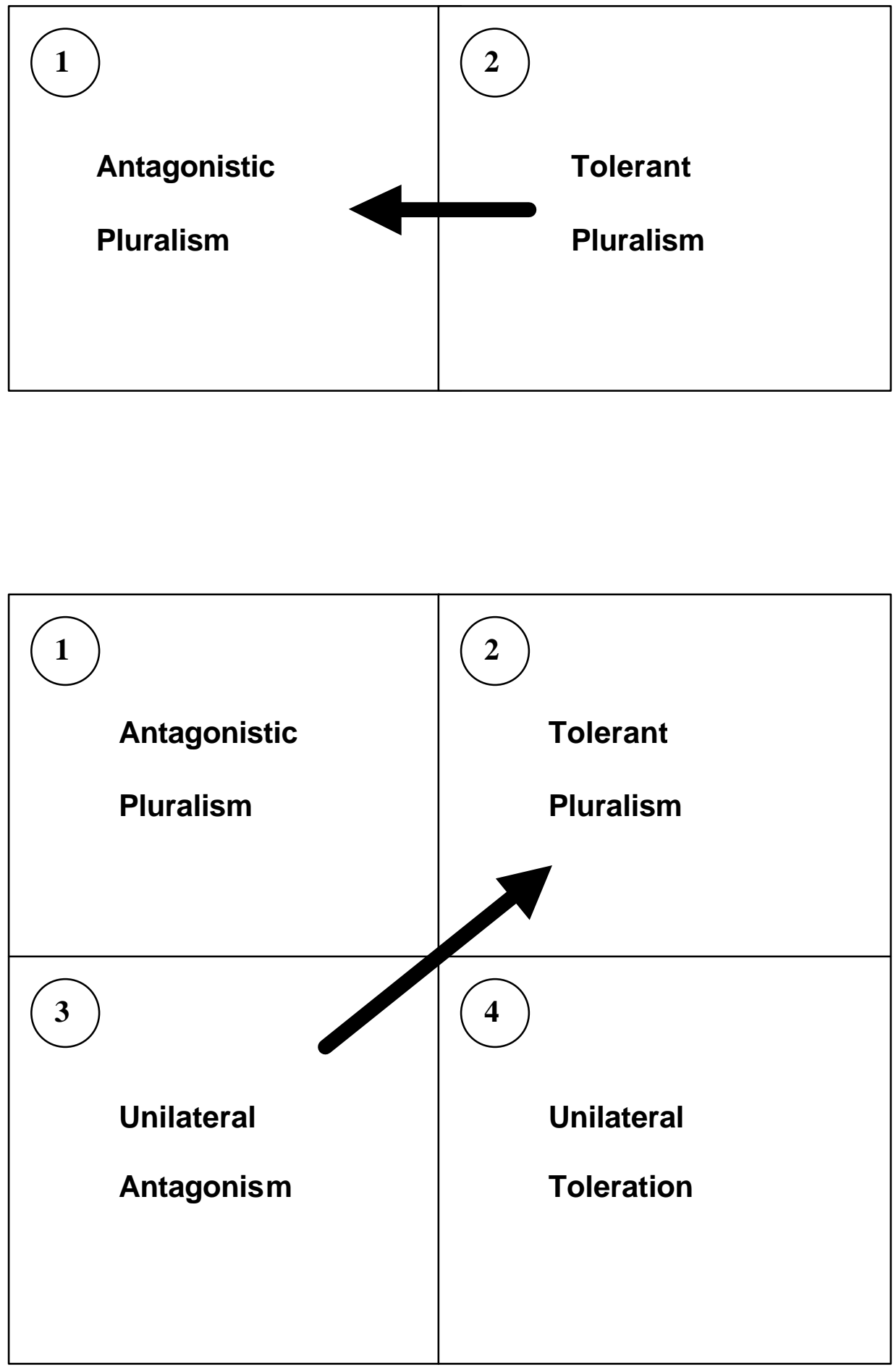